\title{
STUDI PERKEMBANGAN SUBSTANSI KUTIPAN AKTA PERKAWINAN BAGI NON MUSLIM SETELAH BERLAKUNYA UNDANG UNDANG NOMOR 1 TAHUN 1974 PADA DINAS KEPENDUDUKAN DAN CATATAN SIPIL KABUPATEN BANYUMAS
}

\author{
Trusto Subekti \\ Fakultas Hukum Universitas Jenderal Soedirman Purwokerto, Jawa Tengah
}

\begin{abstract}
Article 2 paragraph (2) Law No.1 of 1974 stated that every marriage must be recorded as evidence of the Marriage Certificate issued. Viewed from the aspect of history, marriage records still reflect the political classification of residents based on the Civil Ordinance for the European group No. S.1849. 25, Civil Ordinance for the Chinese S. No. 1917. 1919 No. 130 Jo. 81, Civil Ordinance for class citizen Christian Original S. No. 19,330. 1936 No. 75 Jo. 607. In Indonesia the law of political developments have led to no longer recognize classification population. Since 1966, has issued instructions of the Cabinet Presidium Ampera No. 31/U/IN/12/1966 and followed-up by the Presidential Decree No.12 Year 1983, and finally Law No. 23 Year 2006 concerning Population and Administrative and Regulation No.37 Year 2007 as its implementing regulations. Recording of marriage is a state of institutional behavior and decision or reflect the will of the state establishment, and the product of a decision or other form of establishment of the Marriage Act and Marriage Act quotation. If the Marriage Act's passage can be read law and political unknown and the state of institutional readiness in implementing its mission. This study aims to determine the development of the Marriage Act Excerpt substances, particularly applicable to non-Muslim population The approach used in research is a normative juridical and the results obtained is that the study of the development of the Marriage Act Excerpt substance for non-Muslims in touch with the historical aspects that show the existence of variation.
\end{abstract}

Keywords: Growth, Quotes Marriage Act, Non-Muslims

\begin{abstract}
Abstrak
Pasal 2 ayat (2) UU No.1 Tahun 1974 menyatakan bahwa setiap perkawinan harus dicatat sebagai bukti Akta Nikah yang diterbitkan. Dilihat dari aspek sejarahnya, catatan perkawinan masih mencerminkan pergolongan politik warga dengan mendasarkan pada Ordonansi Sipil untuk kelompok Eropa S.1849 No. 25 Ordonansi, Sipil untuk Cina S. No. 1917. 1919 Nomor 130 Jo. 81, Ordonansi Sipil untuk warga kelas Kristen Asli S. No. 19.330. 1936 Nomor 75 Jo. 607. Di Indonesia hukum perkembangan politik telah menyebabkan penduduk tidak lagi mengenali pergolongannya. Sejak tahun 1966, pemerintah telah mengeluarkan instruksi Presidium Kabinet Ampera No 31/U/IN/12/1966 dan diikuti dengan Keputusan Presiden No 12 Tahun 1983, dan akhirnya Undang-Undang Tentang 23 Tahun 2006 tentang Administrasi Kependudukan serta Peraturan No.37 Tahun 2007 sebagai peraturan pelaksanaannya. Dalam hal ini, pencatatan perkawinan adalah keadaan perilaku institusional dan keputusan atau mencerminkan kehendak pendirian negara, dan produk dari suatu keputusan atau bentuk lain dari pembentukan Undang-Undang Perkawinan dan Undang-Undang Perkawinan kutipan. Jika bagian ini Undang-Undang Perkawinan yang dapat dibaca dan diketahui hukum politik dan negara bagian kesiapan kelembagaan dalam melaksanakan misinya. Tulisan ini bertujuan untuk menentukan perkembangan tentang Kutipan UU Perkawinan, terutama berlaku untuk penduduk non-Muslim Pendekatan yang digunakan dalam tulisan ini adalah yuridis normatif dan hasil yang diperoleh adalah bahwa studi tentang pengembangan substansi UU Perkawinan, khususnya tentang kutipan untuk nonMuslim berhubungan dengan aspek-aspek historis yang menunjukkan adanya variasi.
\end{abstract}

Kata kunci: Pertumbuhan, Kutipan UU Perkawinan, Non-Muslim 


\section{Pendahuluan}

Perkawinan dapat dilihat sebagai dasar dari sistem sosial yang beradab dan Muhammad Ali dalam bukunya "De relegie van den Islam" menyatakan bahwa keluarga yang merupakan kesatuan yang nyata dari bangsa-bangsa manusia, yang menyebabkab terciptanya peradaban hanyalah mungkin diwujudkan dengan perkawinan. Tanpa perkawinan tidak ada keluarga dan dengan sendirinya tidak ada pula unsurunsur yang mempersatukan bangsa manusia, selanjutnya tidak ada peradaban ${ }^{1}$.

Sistem sosial menurut Nasikun dikatakan bahwa sebagai suatu sistem dari berbagai tindakan-tindakan, yang terbentuk dari interaksi sosial yang terjadi diantara berbagai individu, yang tumbuh dan berkembang tidak secara kebetulan, melainkan tumbuh dan berkembang di atas standar penilaian umum yang disepakati bersama oleh para anggota masyarakat $^{2}$. Selanjutnya dilihat dari konsepsi hukum sebagai alat untuk merubah masyarakat (Law as a tool of social engineering), telah dirumuskan konsep perubahan dibidang hukum keluarga dan perkawinan berupa ide pembaharuan dan ide unifikasi hukum ${ }^{3}$. Melalui ide pembaharuan dirumuskan konsep-konsep yang mengarahkan perubahan masyarakat Indonesia secara nasional yang dan melalui ide unifikasi hukum maka konsep perubahan masyarakat tersebut dipaksakan kepada seluruh warga masyarakat Indonesia.

Pengertian kawin atau perkawinan secara umum dipahami sebagai menjalin kehidupan baru dengan bersuami atau beristeri, menikah, melakukan hubungan seksual, dan bersetubuh ${ }^{4}$; dan disamping itu juga ada berbagai pemahaman mengenai perkawinan dari berbagai perspektif agama maupun budaya (adat) yang berbeda-beda sesai dengan kebinekaan suku bang-

Muhammad Ali, dalam Soemiyati, 2007, Hukum Perkawinan Islam dan Undang-undang Perkawinan (Undang-undang No. 1 Tahun 1974, Tentang Perkawinan), Yogyakarta: Liberty, hlm. 17.

2 Nasikun, 1986, Sistem sosial Indonesia, Jakarta: Rajawali, hlm. 12-13.

3 M. Yahya Harahap , 1975, Hukum Perkawinan Nasional, Medan: CV. Zahir Trading Co, hlm. 5-10

4 Em Zul Fajri dan Ratu Aprilia Senja, 2005, Kamus Lengkap Bahasa Indonesia, Jakarta: Difa Publisher, hlm. 432. sa di Indonesia. Dalam perspektif Islam pernikahan atau perkawinan itu dipandang bukan hanya sebagai suatu sakramen saja, tetapi merupakan kontrak yang dibuat oleh kedua belah pihak $^{5}$, oleh karena itu suatu ditegaskan oleh Abdul Ghofur Anshori, bahwa pernikahan atau perkawinan juga merupakan kesepakatan kedua belah pihak $^{6}$; dengan demikian berlaku pula asas-asas perjanjian dan ruang lingkupnya berada dalam hukum keluarga.

Perkawinan sangat penting karena suatu perkawinan yang sah menjadikan perhubungan antara pria dengan wanita menjadi terhormat dalam pergaulan kemasyarakatannya. Selain itu dalam hubungan keluarga terdapat pula makna pembinaan dan pengaturan sebagai tatanan hubungan antar manusia yang tertib dan teratur $^{7}$, sehingga pemahaman mengenai perkawinan dan keluarga akan dapat dipergunakan sebagai sarana bagi manusia untuk menunaikan kehidupannya di dunia ${ }^{8}$. Sehubungan dengan itu dipandang perlu oleh Pembentuk Undang Undang diberikan rumusan mengenai pengertian perkawinan sebagaimana disebutkan dalam Pasal 1 UU No. 1 Tahun 1974 tentang Perkawinan, selanjutnya akan disebut UU No. 1 Tahun 1974 yang menentukan bahwa

Perkawinan ialah ikatan lahir bathin antara seorang pria dengan seorang wanita sebagai suami isteri dengan tujuan membentuk keluarga (rumah tangga) yang bahagia dan kekal berdasarkan Ketuhanan Yang Maha Esa.

Pasal $1 \mathrm{di}$ atas berisi idealisme perkawinan dan konsep keluarga dipahami dalam pengertian keluarga inti (nucleus family), yaitu sebagai suatu basic dari suatu susunan masyarakat (basic social structure dan sahnya perkawinan diatur pada Pasal 2 UU No. 1 Tahun 1974 yang menentukan bahwa

\footnotetext{
Seyyed Hossein Nasr, 2003, Islam: Agama Sejarah dan Peradaban, Surabaya: Risalah Gusti, hlm. 80.

6 Abdul Ghofur Anshori, 2006, Pokok-Pokok Hukum Perjanjian Islam di Indonesia, Yogyakarta: Citra Media, hlm. 26.

7 Abdul Manan, 2005, Aspek-Aspek Pengubah Hukum, Jakarta: Prenada Media, hlm. 4.

8 Samson Rahman, 2007, Islam Moderat: Menebar Islam Rahmatan Lil Alamin, Jakarta: Pustaka IKAD, hlm. 13.
} 
(1) Perkawinan adalah sah, apabila dilakukan menurut hukum masing-masing agamanya dan kepercayaannya itu.

(2) Tiap-tiap perkawinan dicatat menurut peraturan perundang-undangan yang berlaku.

Maksud frase hukum masing-masing agamanya dan kepercayaannya itu adalah termasuk ketentuan-ketentuan perundang-undangan yang berlaku bagi golongan agamanya dan kepercayaannya itu sepanjang tidak bertentangan atau tidak ditentukan lain dalam undang-undang ini ${ }^{9}$. Sahnya perkawinan harus ditafsirkan secara sistematis dengan memahami Pasal 2 ayat (1) UU No. 1 Tahun 1974 dan dihubungkan dengan persyaratan perkawinan yang terdiri dari syarat materiil (Pasal 6 sampai dengan Pasal 11 UU No. 1 Tahun 1974) dan syarat formil (Pasal 12 UU No. 1 Tahun 1974). Selain itu Pembentuk Undang Undang melalui ketentuan Pasal 2 ayat (2) UU No. 1 Tahun 1974 telah mewajibkan bahwa setiap perkawinan harus dicatatkan dan ditegaskan pula dalam PP No. 9 Tahun 1975 bahwa sebagai bukti pencatatan perkawinan tersebut diterbitkan Akta Perkawinan.

Akta Perkawinan merupakan produk tindakan administrasi negara yang berupa penetapan, apabila Kutipan Akta Perkawinan itu dibaca substansinya (isinya) akan dapat diketahui pandangan politik hukum, serta kesiapan kelembagaan negara dalam rangka melaksanakan misinya. Selanjutnya dari perubahan dan perkembangan Kutipan Akta Perkawinan tersebut juga dapat diketahui aspek kesejarahannyaan dan adakah sinkronisasi antara UU No. 1 Tahun 1974 dan PP No. 9 Tahun 1975 dengan UU No. 23 Tahun 2006 tentang Administrasi Kependudukan, selanjutnya disebut UU No. 23 Tahun 2006 dan PP No. 37 Tahun 2007 Pelaksanaan UU No, 23 Tahun 2006 tentang Administrasi Kependudukan, selanjutnya disebut PP No. 37 Tahun 2007.

Pelaksanaan UU No. 23 Tahun 2006 beserta PP No. 37 Tahun 2007 masih dalam proses

Sudarsono, 1991, Hukum Perkawinan Nasional, Jakarta: Rineka Cipta, hlm. 10. pembenahan secara kelembagaan sampai tingkat PERDAnya, untuk itu dirasa perlu dan penting dilakukan studi terhadap perkembangan substansi Kutipan Akta Perkawinan. Dalam penelitian ini hanya dibatasi obyek kajiannya pada Kutipan Akta Perkawinan bagi Non Muslim saja, dengan lokasi penelitian pada Kantor Dinas Kependudukan dan Catatan Sipil Kabupaten banyumas.

\section{Pembahasan}

\section{Pencatatan Perkawinan}

Setelah seluruh prosesi perkawinan selesai dilakukan (Pasal 10 ayat (1), (2) dan (3) PP No. 9 Tahun 1975), kemudian Akta Perkawinan ditanda tangani oleh kedua mempelai, kedua orang saksi dan Pegawai Pencatat yang menghadiri perkawinan. Bagi orang-orang yang beragama Islam, akta perkawinan ditandatangani pula oleh wali nikah atau yang mewakilinya; sejak saat itulah secara yuridis peristiwa perkawinan yang dilaksanakan telah tercatat secara resmi (Pasal 11 ayat (1),(2),(3) PP. No. 9 Tahun 1975).

Pencatatan perkawinan menurut Pasal 3 s/d Pasal 9 PP No. 9 Tahun 1975 berlaku pula bagi mereka yang Pencatatan Perkawinannya dilakukan berdasarkan: Ordonansi Catatan Sipil untuk Golongan Eropa (Stbl. 1849-25), Ordonansi Catatan Sipil untuk Golongan Cina, (Stbl. 1917 - 130 yo 1919 - 81), Ordonansi Catatan Sipil untuk Golongan Kristen Indonesia, (Stbl. 1933 - 279 yo 1936 - 607), Ordonansi Catatan Sipil untuk Perkawinan Campuran (Stbl- 1904279) dan mereka yang tidak tunduk kepada ke empat Ordonansi tersebut dan mereka yang tidak tunduk pada Undang-undang No. 22 Tahun 1946 yo Undang-undang No. 32 Tahun 1954.

Menurut Keputusan Menteri Dalam Negeri No. 131 Tahun 1997 Tentang Penyelenggaraan Catatan Sipil dalam Kerangka Sistem Informasi Manajemen Kependudukan ada perbedaan proses pencatatan perkawinan bagi muslim dan non muslim. Bagi penduduk Indonesia muslim antara tatacara pencatatan perkawinan dengan tatacara perkawinannya merupakan satu rangkaian proses (Pasal $3 \mathrm{~s} / \mathrm{d}$ Pasal 11 PP No. 9 Tahun 1975), sedangkan bagi penduduk Indonesia 
non muslim bahwa pencatatan perkawinannya paling lambat 30 (tiga puluh) hari kerja sejak peristiwa perkawinan dilangsungkan, dan selebihnya harus mendapatkan penetapan pengadilan. Ketentuan tersebut di atas diubah dengan Permendagri No. 28 Tahun 2005 Tentang Pedoman Penyelenggaran Pendaftaran Penduduk dan Pencatatan Sipil Daerah, bahwa perkawinan bagi non muslim yang telah dilakukan menurut hukum agama dan kepercayaannya dicatat oleh unit kerja yang mengelola pendaftaran penduduk dan pencatatan sipil di kabupaten/kota tempat peristiwa perkawinan paling lama 60 (enam puluh) hari kerja sejak peristiwa perkawinan, kemudian Perkawinan dimaksud dicatat oleh Pejabat Pencatat Sipil pada Register Akta Perkawinan dan diterbitkan Kutipan Akta Perkawinan. Ketenuan tersebut dipertegas lagi dalam Pasal 34 ayat (1) UU No. 23 Tahun 2006 bahwa perkawinan yang sah berdasarkan ketentuan Peraturan Perundangundangan wajib dilaporkan oleh Penduduk kepada Instansi Pelaksana (Kantor Dinas Kependudukan Dan Catatan Sipil) di tempat terjadinya perkawinan paling lambat 60 (enam puluh) hari sejak tanggal perkawinan. Pelaporan perkawinan yang dilakukan oleh Penduduk yang beragama Islam kepada KUA Kecamatan, kemudian data hasil pencatatan atas peristiwa sebagaimana dimaksud pada ayat (4) dan dalam Pasal 8 ayat (2) wajib disampaikan oleh KUA Kecamatan kepada Instansi Pelaksana paling lambat 10 (sepuluh) hari setelah pencatatan perkawinan dilaksanakan; oleh Kantor Dinas Kependudukan Dan Catatan Sipil tidak perlu lagi diterbitan kutipan akta perkawinan, karena sudah dibuat oleh KUA.

Ketentuan-ketentuan mengenai pencatatan perkawinan sebagaimana diatur dalam UU No. 23 Tahun 2006 dan PP No. 37 Tahun 2007 serta Perpres No. 25 Tahun 2008 sampai saat ini belum bisa dilaksanakan sepenuhnya di Kabupaten Banyumas, oleh karena itu tatacara pencatatan perkawinan bagi penduduk di Kabupaten Banyumas masih menggunakan Peraturan Daerah Kabupaten Banyumas No. 5 Tahun 2005 Tentang Pengelolaan Penyelenggaraan Pelayanan Catatan Sipil, Peraturan Daerah Kabupaten
Banyumas No. 6 Tahun 2005 Tentang Retribusi Penggantian Biaya Cetak Akta Catatan Sipil dan Peraturan dan Peraturan Bupati Banyumas No. 17 Tahun 2005 Tentang Prosedur Dan Tatacara Penyelenggaraan Pelayanan Catatan Sipil.

Sebelum melangsungkan perkawinan kedua mempelai harus memberitahukan kehendaknya untuk melangsungkan perkawinan kepada Pegawai Pencatat Perkawinan di tempat perkawinan akan dilangsungkan (Pasal 3 ayat (1) dan ayat (2) PP No. 9 Tahun 1975 jo. Pasal 9 Peraturan Daerah Kabupaten Banyumas No. 5 Tahun 2005 dan ketentuan Pasal 8 ayat (1) Peraturan Bupati Banyumas No. 17 Tahun 2005), dengan menyerahkan syarat pencatatan perkawinan.

Syarat umum meliputi Surat Model N1 s/d N4 dari Desa dan diketahui Camat terdiri dari Surat Keterangan untuk menikah, keterangan asal usul, persetujuan mempelai, keterangan tentang orang tua; Photo copy KTP dan KK dari mempelai dan orang tua yang masih berlaku dan telah dilegalisir yang berwenang/menunjukkan aslinya; Photo copy akta kelahiran masing-masing calon mempelai yang dilegalisir oleh instansi yang berwenang/menunjukkan aslinya atau surat kenal lahir; Photo copy akta perkawinan/surat nikah orang tua yang telah dilegalisir yang berwenang/menunjukkan aslinya; Dua orang saksi dari masing-masing mempelai dan photo copy KTP saksi yang masih berlaku/menunjukkan aslinya; Surat pernyataan belum menikah bermaterai cukup, diketahui Lurah/Kepala Desa; Pas photo mempelai berdampingan (suami sebelah kanan isteri) ukuran $4 \times 6 \mathrm{~cm}$ sebanyak 5 (lima) lembar; Surat keterangan dokter dari RSU/DKK/Puskesmas (bagi kedua mempelai); Surat keterangan imunisasi (TT1) dan (TT2) dari dokter RSU/DKK/ Puskesmas (untuk mempelai wanita); Surat Baptis/surat keterangan keagamaan yang bersangkutan (Pasal 9 huruf a Peraturan Bupati Banyumas No. 17 Tahun 2005); Surat keterangan /photo copy surat pemberkatan perkawinan dari pemuka agama/menunjukkan aslinya.

Sedangkan syarat khusus meliputi Akta perceraian asli bagi yang pernah kawin; Photo copy akta kematian/surat kenal mati pasang- 
annya bagi mempelai janda atau duda; Akta Izin Kawin bagi mempelai pria yang sudah berusia 19 tahun dan mempelai wanita yang sudah berusia 16 tahun tetapi belum berusia 21 tahun. Bagi calon mempelai pria yang berusia kurang dari 19 tahun dan calon mempelai wanita yang berusia kurang dari 16 tahun harus memeperoleh izin dari Pengadilan Negeri; Akta Notaris perjanjian perkawinan untuk pengesahan perjanjian harta terpisah bagi pasangan mempelai yang berkehendak memisahkan harta harta diluar harta bersama; Bagi WNA melampirkan surat pengantar dari Keduataan Besar Negara yang bersangkutan dan Photo copy Dokumen Imigrasi (Paspor, Visa, ID Card, STND); Surat Izin dari Komandan bagi anggota dan POLRI; Apabila salah satu calon mempelai berdomisili tetap diluar Kabupaten Banyumas maka dilengkapi dengan pengumuman perkawinan (Pasal 9 huruf b Peraturan Bupati Banyu-mas No. 17 Tahun 2005.

Berdasar atas ketentuan Pasal 10 Peraturan Bupati Banyumas No. 17 Tahun 2005 ditentukan prosedur pencatatan dan penerbitan akta perkawinan, sebagai berikut:

1) Pemohon (pasangan mempelai, orang tua atau kuasanya) mengisi formulir pelaporan perkawinan.

2) Melampirkan persyaratan sebagaimana diatur dalam Pasal 9 Peraturan Bupati Banyumas No. 17 Tahun 2005.

3) Pencatatan Perkawinan dilakukan setelah 10 (sepuluh) hari kerja sejak tanggal pendaftaran perkawinan untuk kedua pasangan mempelai yang bertempat tinggal tetap di wilayah Kabupaten Banyumas dan atau 15 (lima belas) hari kerja sejak tanggal pendaftaran perkawinan bagi salah satu calon mempelai yang berdomisili tetap di luar Kabupaten Banyumas.

4) Pencatatan Perkawinan kurang dari 10 (sepuluh) hari kerja bagi kedua pasangan mempelai yang bertempat tinggal tetap di wilayah Kabupaten Banyumas dan atau 15 (lima belas) hari kerja bagi salah satu pasangan mempelai yang bertempat tinggal tetap di luar wilayah Kabupaten Banyumas melengkapi Surat Dispensasi dari Camat dari salah satu pasangan mempelai bertempat tinggal tetap di wilayah Kabupaten Banyumas.

5) Proses sidang peneguhan pencatatan perkawinan dilaksanakan di hadiri oleh kedua mempelai dan saksi-saksi dari masingmasing kedua pasangan mempelai yang bersangkutan dan orang tua bagi pasangan mempelai yang berumur kurang dari 21 (dua puluh satu) tahun.

6) Pencatatan Perkawinan bagi pasangan mempelai yang tunduk pada S. 1849-25 tentang Pencatatan Sipil golongan Eropa dan S. $1917-130$ jo. S.1919-81 tentang Pencatatan Sipil golongan Tionghoa dapat sekaligus dilaksanakan Pencatatan Pengakuan dan pengesahan anak luar kawin bagi pasangan mempelai yang telah mempunyai anak luar kawin sebelum pengesahan perkawinan dilaksanakan.

7) Pencatatan Perkawinan bagi pasangan mempelai non muslim yang tunduk pada $\mathrm{S}$. 1933-75 jo. S. 1936-607 tentang Pencatatan Sipil bagi Bangsa Indonesia, Kristen, Jawa, Madura dan Minahasa S. 1920-757 jo. S. 1927-564 dan non Staatsblad dapat sekaligus dilaksanakan pengesahan anak luar kawin bagi mempelai yang telah mempunyai anak luar kawin sebelum pengesahan perkawinan dilaksanakan.

8) Dalam Pencatatan Perkawinan dapat dicatat sekaligus pengesahan perjanjian perkawinan dari akta Notaris tentang Perjanjian Harta Terpisah dalam perkawinan sesuai ketentuan peraturan Per Undang-Undangan yang berlaku.

\section{Perkembangan Substansi Kutipan Akta Per- kawinan}

Akta Perkawinan dibuat rangkap dua, helai pertama disimpan oleh Pegawai Pencatat, helai kedua disimpan pada Panitera Pengadilan dalam wilayah Kantor Perkawinan itu berada, sedangkan kedua suami istri masing-masing diberi Kutipan Akta Perkawinan (Pasal 13 PP No. 9 Tahun 1975). Selanjutnya dari hasil penelitian di Kantor Dinas Kependudukan dan Catatan Sipil Kabupaten Banyumas ditelusuri secara 
historis dari masa lalu, yaitu sejak sebelum diundangkannya UU No. 1 Tahun 1974 dan PP No. 9 Tahun 1975 dapat digambarkan bahwa pada awalnya Akta Perkawinan atau Kutipan Akta Perkawinan ditulis dengan menggunakan kertas Segel, artinya belum diterbitkan blanko Kutipan Akta Perkawinan yang baku. Baru kemudian mulai berkembang beberapa model blanko Kutipan Akta Perkawinan dengan format yang dibakukan seperti sekarang ini.

Hasil penelusuran sejarah tentang isi Kutipan Akta Perkawinan diperoleh penjelasan secara kronologis bahwa Peraturan perundangundangan sebelum tahun 1974, masih berdasar atas Pasal 131 dan Pasal 163 I.S. maka akan berpengaruh terhadap produk-produk yang dibuat oleh Catatan Sipil di Indonesia misalnya terhadap Kutipan Akta Perkawinan. Di dalam "kepala" Kutipan Akta Perkawinan masih tertulis kata "Golongan", dan pada permulaan ikhtisar Kutipan Akta Perkawinan memakai perkataan "Golongan Eropa" atau "Golongan Tionghoa (Cina)" 10; Sejak dikeluarkannya Instruksi Presidium Kabinet No. 31/U/In/12/1966 tanggal 27 Desember 1967 telah menghapuskan golongan penduduk Indonesia, walaupun dalam Instruksi Presidium tersebut masih menggunakan Staatsblad dalam hal peraturan Catatan Sipil bukan berarti ada diskriminasi penduduk Indonesia. Dijelaskan bahwa di dalam Kutipan Akta Perkawinan perkataan "Golongan" pada "Kepala" iktisar Kutipan Akta Catatan Sipil itu diganti dengan perkataan "Warga Negara Indonesia" dan untuk orang asing menggunakan perkataan "Warga Negara : ........" dengan diisi nama negara yang bersangkutan. Jika kewarganegaraannya tidak jelas, ditulis perkataan “Tanpa Kewarganegaraan"11; Pada permulaan ikhtisar Kutipan Akta Perkawinan yang memakai perkataan-perkataan "Untuk Golongan Eropa" atau “ Untuk Golongan Tionghoa” diganti dengan perkataan "Menurut Stb ............. no ." dengan diisi Stb yang bersangkutan, yaitu Stb. 1849 no 25 untuk Golongan Eropa,

\footnotetext{
Soedjito Tjokrowisastro, 1985, Pedoman Penyelenggaraan Catatan Sipil, Jakarta: PT. Bina Aksara, hlm. 260.
}

$11 \quad$ Ibid, hlm. 260
Stb. 1917 no 130 jo 1919 no 81 untuk Golongan Tionghoa dan Stb. 1933 no 75 Jo 1936 no 607 untuk golongan WNI Asli yang beragama Kristen ${ }^{12}$. Dengan demikian penggunaan Staatblaad adalah untuk mengganti perkataan golongan sehingga tidak ada kesan diskriminasi penduduk Indonesia; Apabila dilihat dari isi Akta Perkawinan yang diatur dalam Keputusan Menteri Dalam Negeri No 221 a tahun 1975 maka dapat dilihat bahwa Akta Perkawinan tersebut, tidak mencerminkan isi dari Pasal 2 ayat (1) UU No 1 tahun 1974 karena di sana tertulis “..............Pegawai Luar Biasa Pencatat Sipil/ Pejabat Khusus telah melangsungkan perkawinan". Dari bunyi Akta Perkawinan tersebut, menerangkan bahwa catatan sipil melangsungkan perkawinan yang sekaligus mencatat perkawinan, padahal menurut Pasal 2 ayat (1) UU No 1 tahun 1974 catatan sipil hanya mencatat perkawinan yang telah terjadi atau yang telah dilangsungkan menurut hukum masing-masing agamanya dan kepercayaannya itu, dan tidak melangsungkan perkawinan atau mengesahkan perkawinan; Sejak tahun 1990-an isi Akta Perkawinan tersebut mengalam perubahan, yaitu yang menerangkan bahwa Catatan Sipil mencatat perkawinan saja, sehingga kalimat "Melangsungkan Perkawinan" diganti dengan kalimat "Mencatat Perkawinan", sehingga hal ini telah mencerminkan isi dari Pasal 2 ayat (2) UU No 1 tahun 1974 yang hanya mencatat peristiwa perkawinan yang telah terjadi. Setelah perkawinan tersebut dicatat, maka perkawinan tersebut telah tercatat seara resmi. (Pasal 11 ayat (3) PP No 9 tahun 1975). Kemudian berdasar Pasal 13 PP No 9 Tahun 1975 Akta Perkawinan tersebut harus dibuat rangkap dua, yaitu helai pertama disimpan oleh Pegawai Pencatat, dan helai kedua disimpan pada Panitera Pengadilan dalam wilayah Kantor pencatatan perkawinan itu berada. Adapun untuk suami dan isteri masing-masing diberi Kutipan Akta Perkawinan.

Telah diuraikan di atas, bahwa UU No 1 tahun 1974 dan PP No 9 tahun 1975 tidak mengatur tentang format Kutipan Akta Perkawinan,

$12 \quad$ Ibid, hlm. 260. 
tetapi format Kutipan Akta Perkawinan diatur oleh Keputusan Menteri Dalam Negeri No 221 a tahun 1975 tentang Pencatatan Perkawinan dan Perceraian pada Kantor Catatan Sipil sehubungan dengan berlakunya Undang-Undang Perkawinan dan Peraturan Pelaksanaannya. Adapun format Kutipan Akta Perkawinan pada Dinas Kependudukan dan Catatan Sipil Kabupaten Banyumas ada beberapa model, meliputi Pertama, Model 1 Kutipan Akta Perkawinannya berisi tentang Tanggal dan nama kota dilangsungkannya perkawinan, dan belum mencerminkan UU No 1 Tahun 1974 karena tidak mencatat tentang pemuka agama yang melangsungkan perkawinan serta tempat dilangsungkannya perkawinan; Kedua, Model 2 Kutipan Akta Perkawinan berisi tanggal dan nama kota dilangsungkannya perkawinan tetapi juga berisi tentang tempat dilangsungkannya perkawinan dan nama pemuka agama yang melangsungkan perkawinan, berarti telah mencerminkan UU No 1 tahun 1974; Ketiga, Model 3 Kutipan Akta Perkawinan sudah mencerminkan UU No. 1 Tahun 1974 dan dalam perkembangannya Kutipan Akta Perkawinan sudah menggunakan format yang sama bagi pemeluk agama yang berbeda-beda. Selanjutnya format dari blanko Kutipan Akta Perkawinan telah mengalami perubahan dan agaknya mulai mencerminkan pandangan kearah globalisasi sehingga dalam penulisannya dituliskan dalam dua bahasa, yaitu dalam bahasa Indonesia dan bahasa Inggris.

Sejalan dengan telah diterbitkannya UU No. 23 Tahun 2006 Tentang Administrasi Kependudukan (walau secara operasional teknisnya belum diatur secara rinci pada setiap Kabupaten) namun telah diupayakan diterapkan dalam praktik penulisan pada Kutipan Akta Perkawinan. Selanjutnya dalam model 3 diatas telah tercantum kode NIK (Nomor Induk Kependudukan), maka sejak saat itulah format blanko Kutipan Akta Perkawinan digunakan format yang sama untuk seluruh perkawinan dengan tidak membeda-bedakan agama atau penduduk di Indonesia. Selain itu menurut keterangan Petugas Pencatat Perkawinan masih ada yang dirasa kurang pas dengan masih dicantumkan Stbld (Staatsblad) dalam Kutipan
Akta Perkawinan pada model 3 tersebut yang seolah-olah masih mencerminkan masih adanya pandangan pergolongan penduduk di Indonesia, walau dalam praktiknya pada bagian stbld tersebut dituliskan UU No. 23 Tahun 2006 (UU tentang Administrasi Kependudukan). Dengan demikian pencatuman Staatblaad pada Akta Perkawinan maupun Kutipan Akta Perkawinan sudah tidak berlaku lagi, sehingga perlu dihapuskan.

\section{Penutup \\ Simpulan}

Berdasarkan uraian tersebut di atas, maka dapat ditarik kesimpulan bahwa substansi Kutipan Akta Perkawinan dari masa ke masa telah mengalami perkembangan dari pandangan yang mencerminkan adanya penggolongan penduduk kearah tidak lagi mengenal perbedaan golongan penduduk maupun agama di Indonesia, meliputi Pertama, Model 1 belum mencantumkan nama pemuka agama yang melangsungkan perkawinan; Kedua, Model 2 telah mencantumkan nama pemuka agama yang melaksanakan perkawinan; Ketiga, Model 3 yang telah diberlakukan sama bagi semua penduduk di Indonesia dengan tidak membedakan golongan penduduk maupun agama. Namun dari ketiga model Kutipan Akta Perkawinan tersebut masih mencantumkan Stbld (Staatsblaad) sebagai dasar hukum pencatatan perkawinan, walau dalam praktiknya sekarang yang dicantumkan dalam Stbld tersebut adalah UU No. 23 Tahun 2006.

\section{Saran}

Format Substansi Kutipan Akta Perkawinan pada baris kedua yang berbunyi menurut Stbld seyogyanya dihapuskan saja supaya lebih tegas mencerminkan politik hukum Indonesia yang tidak lagi mengenal adanya perbedaan golongan penduduk. 